\section{UK launches department to focus on climate change}

UK prime minister Gordon Brown has created a Department of Energy and Climate Change.

The announcement, made on 3 October as part of a wider reorganization of the government, was widely praised by environmentalists, who hope that the department will unify the nation's efforts to reduce greenhouse-gas emissions. It will be led by Ed Miliband, who is regarded as a close ally of the prime minister and whose brother, David, is the foreign secretary.

Previously, climate change and energy policy in the government were spread across several agencies. "It was a bit of a mess, actually," says Ben Caldecott, head of the environment unit at Policy Exchange, a London-based think tank. Caldecott calls the new climate-change department "a step in the right direction", but says more must be done to unify policy.

The government reshuffle has also ushered in a new science minister. Paul Drayson, a multimillionaire and former head of Defence Equipment and Support, the UK defence ministry's procurement organization, will replace Ian Pearson. Drayson holds a $\mathrm{PhD}$ in robotics from Aston University.

\section{US academic fleet cuts operations as budget bites}

Budget freezes and high fuel costs will force one vessel in the US academic oceanographic fleet - probably from an East Coast institution - to remain docked throughout 2009. Two other members of the fleet's 23 ships will run on only partial schedules.

At their annual meeting in Arlington, Virginia, last week, council members of

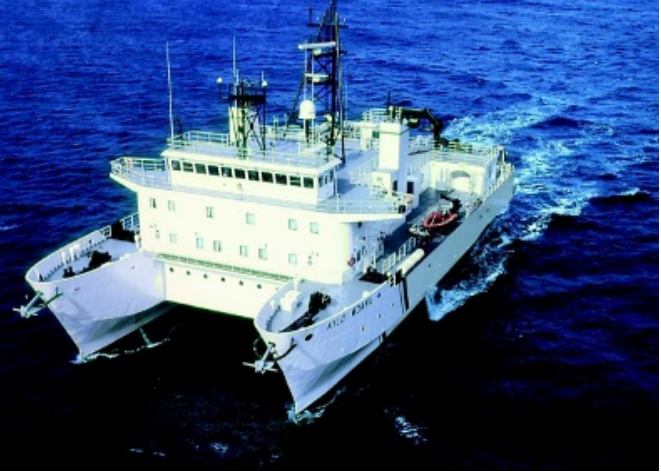

Some of the US research fleet may be suspended.

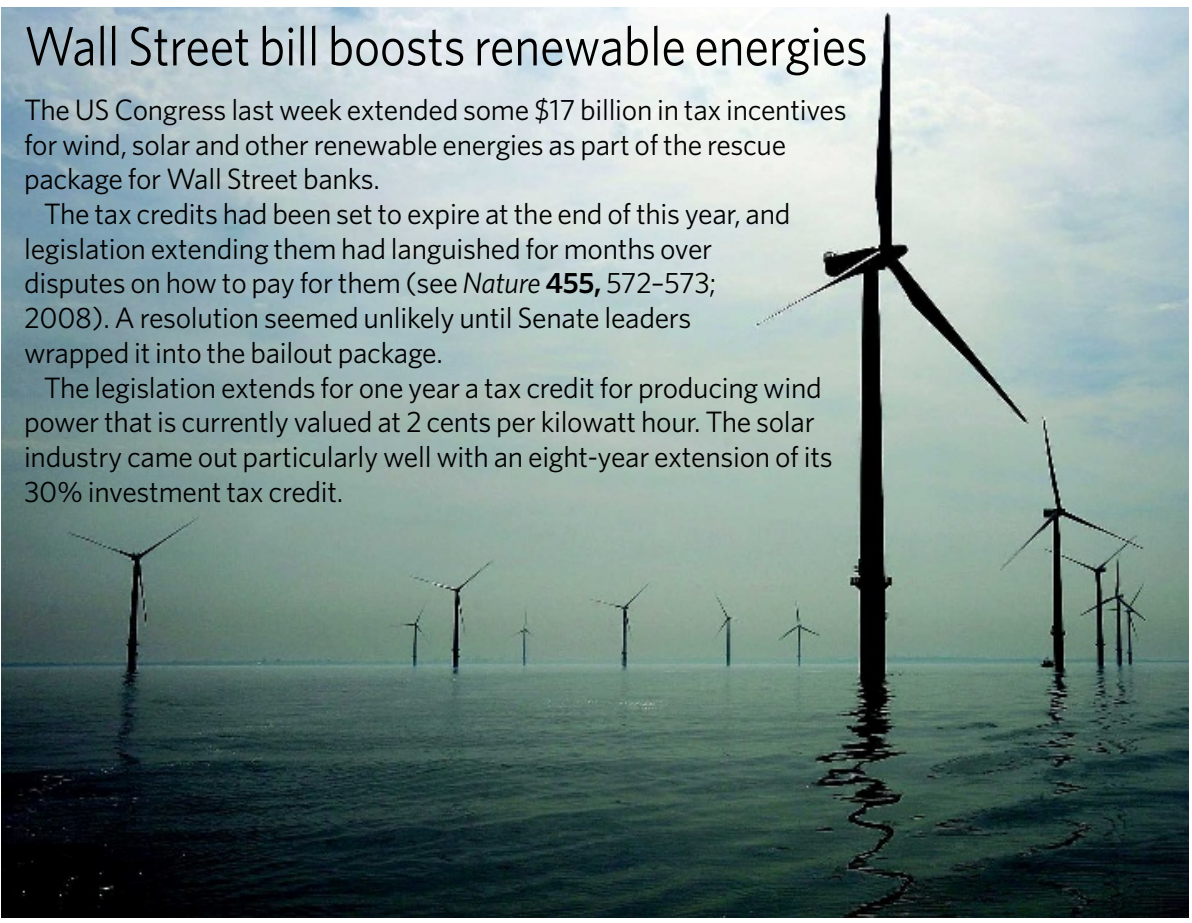

the University-National Oceanographic Laboratories System (UNOLS) said the cutbacks were necessary to save money. Despite sidelining ships, UNOLS still faces one of its largest ever deficits, of \$19 million, in its $\$ 100$-million budget to fund next year's fleet.

Final plans to select the ships and strategies to cover the deficit will be made by the end of October.

\section{Italy to create biomedical- research funding system}

The Italian government has pledged to create a formal system for the competitive distribution of funds for biomedical research, which will conform to international standards of peer review and transparency.

The statement of intent has partially mollified biologists, some of whom last year protested the murky allocation of research funds by the ISS, Italy's health-research institute in Rome. Stem-cell researchers were particularly angry about how funds earmarked for their field were distributed (see Nature 450, 320; 2007).

The health ministry, which made the announcement on 1 October, has not yet indicated when the system would come into effect.

\section{Eli Lilly wins race to take control of ImClone}

Pharmaceuticals giant Eli Lilly, of Indianapolis, Indiana, seems to have beaten its rival Bristol-Myers Squibb in the competition for ImClone, a biotechnology firm based in New York. On 6 October, Eli Lilly and ImClone announced that they had agreed to a US\$6.5-billion merger.

Bristol-Myers Squibb, also of New York, owns $17 \%$ of ImClone and has an agreement to market its blockbuster anticancer drug Erbitux (cetuximab), a monoclonal antibody. In July Bristol-Myers Squibb failed in a bid to buy the biotech company, offering \$60 a share, when ImClone's shares were trading at around \$40-45. A follow-up offer of $\$ 62$ a share was also turned down. The Eli Lilly deal values the company at $\$ 70$ a share.

Bristol-Myers Squibb is unlikely to bid again, so agreement with Eli Lilly is being seen as the endgame of the protracted wrangling over the company, Erbitux and promising follow-up monoclonal antibodies.

\section{United States agrees to sell nuclear fuel to India}

India can buy nuclear fuel and technologies from the United States, now that the US Senate has approved the ' 123 deal'.

The vote, along with earlier waivers from the Nuclear Suppliers Group and the International Atomic Energy Agency, makes India the only country with nuclear weapons that can legally engage in nuclear commerce without first having signed the Nuclear Non-Proliferation Treaty.

US secretary of state Condoleezza Rice was to have sealed the deal on a visit to New Delhi last weekend. As Nature went to press, President George W. Bush was expected to sign the deal on 8 October. 